Alan J. Abramson' / Kara C. Billings ${ }^{1}$

\title{
Challenges Facing Social Enterprises in the United States
}

${ }^{1}$ Schar School of Policy and Covernment, George Mason University, 3351 Fairfax Drive, Room 608 - MS 3B1, Arlington, VA, USA, E-mail:aabramso@gmu.edu

\begin{abstract}
:
Hybrid organizations that combine social purpose and profit motive appear to have grown significantly in number in the U.S. in recent decades. However, these organizations, which we call "social enterprises," face challenges that impede their growth and hinder their ability to deliver greater benefits. To better understand what these challenges are, this paper surveys the growing literature on social enterprises which suggests that social enterprises now face these major obstacles: ill-fitting legal forms, obstacles to effective governance, problems in evaluating impact, weak supportive networks, difficulties in raising funding, and management tensions. Deepening understanding of the challenges facing social enterprises should help guide those interested in strengthening public policy toward social enterprise and other aspects of the support system for these organizations.
\end{abstract}

Keywords: social enterprise, United States

DOI: 10.1515/npf-2018-0046

\section{Introduction}

Although their exact numbers remain elusive, hybrid organizations that combine social purpose and profit motive appear to have grown significantly in number in the U.S. and globally in recent decades (Ebrahim, Battilana, and Mair 2014, 82; Kerlin and Gagnaire 2009, 87). These organizations, which we will call "social enterprises," have grown in part because of the benefits associated with them. ${ }^{1}$ Social enterprises can attract new funding to address social problems and arguably also bring new efficiencies, talent, and ideas to social problem solving (Kerlin and Gagnaire 2009, 104-105).

However, while expanding the social enterprise field to achieve greater benefits has significant appeal, it has also become clear that the field faces important challenges that impede its growth and hinder its ability to deliver more benefits. As described in the body of this paper, according to many experts these obstacles include inadequate legal forms, obstacles to effective governance, challenges in evaluating impact, and others. In response, there are now a variety of emerging public policy and other initiatives to address these challenges and strengthen the support system for social enterprise. ${ }^{2}$ The main goal of this paper is to provide some guidance for these support efforts by providing additional clarity about the challenges facing social enterprise. That is, the assumption is that public policy and the broader supportive infrastructure that is being developed for social enterprises should at least in part be aimed at overcoming the particular challenges which the field now faces.

This paper seeks to increase understanding of the challenges facing social enterprise through a review of the existing literature that focuses on these organizations. This literature has grown significantly in recent decades to include both important theoretical and empirical work. While additional research is surely warranted to provide deeper understanding of the social enterprise field, existing studies provide a rich store of knowledge about the operation of social enterprises. To date, these studies have not been thoroughly mined to clarify the challenges confronting social enterprise. To be sure, there are some excellent studies that focus on the obstacles facing social enterprises. However, many of these studies focus on one or two areas of challenge, such as management and governance hurdles, and do not take a comprehensive view; this is the contribution that this paper seeks to make. ${ }^{3}$ Specifically, our review of the existing literature on social enterprise points to six common challenges social enterprises face: (1) ill-fitting legal forms; (2) governance challenges; (3) difficulties in measuring impact; (4) lack of a clear identity; (5) problems in accessing capital; and (6) management tensions.

Alan J. Abramson is the corresponding author.

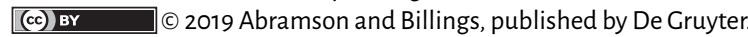

This work is licensed under the Creative Commons Attribution 4.0 Public License. 


\section{III-Fitting Legal Forms}

Leaders of social enterprises have trouble "fitting" their organizations into the current menu of nonprofit and for-profit legal forms, and some of the newer forms, such as benefit corporations and L3Cs, have downsides as well (Battilana and Lee 2014, 410).

\subsection{Nonprofit Social Enterprises}

Social enterprises operating as nonprofits are severely restricted in terms of how they can raise capital. By law, 501(c)(3) charitable nonprofits, the most common type of nonprofit, cannot distribute profits. This constraint limits their access to investors and equity capital, which is an especially appealing source of support for organizations seeking funding since repayment is contingent upon making a profit (Gottesman 2007, 348; Kickul and Lyons 2012, 122). Nonprofits are also somewhat restricted in terms of the earned revenue (e. g. sales of goods and services) they can receive. Any earned income unrelated to a nonprofit's mission is taxed under the Unrelated Business Income Tax (UBIT), and large amounts of unrelated income can put a nonprofit's tax-exempt status at risk.

Social enterprise nonprofits may also have trouble finding other sources of funding that align with their organization. Nonprofits often rely on donations, but social enterprises may find donations in conflict with their goal of self-sufficiency. Crowdfunding and impact investing, which seeks both social and financial returns, are better aligned with social enterprise; however, both are fledgling revenue sources (World Bank 2013; Social Impact Investment Taskforce 2014).

As a result of their funding challenges, social enterprises operating as nonprofits will rarely be able to achieve the growth of for-profit businesses. In the U.S., fewer than 150 nonprofits exceeded $\$ 50$ million in revenue between the 1970s and the 2000s, compared to 50,000 new businesses (Foster and Fine 2007, 46; Social Impact Investment Taskforce 2014). A 2009 survey by Community Wealth Ventures, the Social Enterprise Alliance, and the Center for the Advancement of Social Entrepreneurship at Duke University $(2010,9)$ of 740 social enterprises established by nonprofits in the U.S. or Canada reported that, "Nearly 80 percent of respondents said they needed increased capital to stimulate the growth of their social enterprise." Moreover, more than two-thirds of respondents named "finding funding to start [a] venture" as a challenge they faced in establishing a new social venture. When asked to identify the biggest challenges they face in operating a social venture, the two greatest challenges named were "sales and marketing" and "financial issues" (p. 10).

At least according to some, social enterprises operating as nonprofits are also challenged in terms of the efficiency of their operations. The nonprofit sector has been criticized for failing to use cost-effective practices in fundraising, distributing assets, administering programs, and other areas of operation (Bradley, Jansen, and Silverman 2003). The community-oriented, as opposed to centrally-directed, nature of nonprofits may make for less efficiency. For example, at Goodwill, perhaps the largest nonprofit social enterprise in the country, "resources are gathered and distributed within communities, often without any visibility or controls by those at the center" (Gibbons and Hazy 2015, 9).

In addition, social enterprises may run into trouble finding individuals with business expertise in the nonprofit labor pool. In the 2009 survey of social enterprises, social enterprise nonprofits cited human resources as also among the biggest challenges they face (Community Wealth Ventures et al. 2010, 10). They also expressed a need for greater expertise in sales and marketing, "business plan development, introductory training on social enterprise, market research and analysis, and accessing capital" (p. 11).

At the same time, nonprofits have several advantages over their for-profit counterparts, including exemption from corporate income taxes, the ability to promise tax breaks to donors, and the capacity to attract volunteer labor. Nonprofits also have the competitive advantage of a reputation for doing good. This may explain why nonprofit social enterprises surveyed in 2009 did not see competition with for-profits as a challenge (Community Wealth Ventures, Social Enterprise Alliance, and Center for Advancement of Social Enterprise 2010).

\subsection{For-Profit Social Enterprises}

Meanwhile, social enterprises that choose a for-profit form face significant challenges in making a social or environmental purpose their primary mission. While businesses can include a broad or specific social cause in their articles of incorporation, there is no way to ensure that the mission is prioritized over profit making. Corporate law technically does not require for-profit directors to prioritize profit maximization (Bainbridge 1991; Stout 2012); however, in practice, these directors tend to prioritize profit-seeking because they are beholden to shareholders through fiduciary duty, with shareholders having the ability to remove and/or sue directors who 
do not operate in their interests (Brewer 2016, 45). While some states have passed laws that protect directors from such lawsuits, they have largely failed to translate to a reduced focus on profit maximization (Gottesman 2007,350 ). Theoretically, shareholders could agree to prioritize a social mission, but that is uncommon.

Unlike nonprofits, businesses are not restricted in terms of market-generated capital. They also have the ability to become publicly-owned companies, providing huge growth potential. However, they have heavier tax burdens. For-profit forms generally require double taxation: once on the company and once on individual earnings. Pass-through forms only require one tax on individual earnings, but they may have weaker protections against personal liability and/or a heavier administrative burden (Brewer 2016, 63). Businesses cannot receive tax deductible donations; however, they can get impact investments.

\subsection{Benefit Corporations and L3Cs}

Growing frustration with the menu of options available to social enterprises for incorporation helped give rise to new legal forms for social enterprise in the U.S. and globally. In the U.S., the benefit corporation and the low-profit limited liability company (L3C) have gained the most traction. The authors have described benefit corporations and L3Cs elsewhere (Abramson and Billings forthcoming 2019):

Benefit corporations are similar to traditional corporations except that they must pursue a general public benefit - defined as a "material positive impact on society and the environment" - and can optionally pursue specific public benefits (Callison 2012, 92-94; B Lab 2017b, 3). This creates a "triple bottom line" of profits, social good, and environmental good (Mickels 2009). Benefit corporations are generally established through a separate state law rather than an amendment to corporate law (Brakman Reiser 2011, 595).

The L3C is a variation on the limited liability company (LLC), and states amend LLC law to create the L3C (Esposito 2012, 682). The L3C shares the two dominant qualities of an LLC: limited liability of owners and pass-through tax treatment (Thomson Reuters Foundation 2016, 47-76). The main differences between the two forms are that an L3C's articles of incorporation must specify a charitable or educational purpose as defined by the Internal Revenue Code, and income generation and appreciation of property cannot be significant purposes, thus establishing the precedence of a cause over profit (Brakman Reiser 2013, 690).

Since 2008, when the L3C was first created by Vermont, seven states have authorized the L3C and 32 have authorized the benefit corporation, with roughly 3,000 benefit corporations and 1,000 L3Cs now in existence (B Lab 2017a; Social Enterprise Law Tracker 2017; Cooney et al. 2014).

However, these new forms fail to fully address the problems that spurred their creation. First, neither the L3C or benefit corporation provides any tax benefits to social enterprises, arguably forcing more accountability without extending anything in return. Second, they offer little clarification on reconciling "the problem of serving two masters" (Brakman Reiser and Dean 2017, 19). The benefit corporation even adds a third required "master," environmental good, in addition to social good and profits. This gives little guidance to organizational leaders when, "over the long term, pursuit of profit and social good can be mutually reinforcing. But, at many individual moments, one goal will need to be sacrificed for the other" (Brakman Reiser and Dean 2017, 28). Third, new hybrid legal forms in the U.S. lack regulatory accountability-including a designated government agency with oversight and enforcement powers and annual reporting requirements (Brakman Reiser and Dean 2017, 37-39). While benefit corporations are required to publish a public annual report evaluating the organization's social and environmental performance against an independent third-party standard, "it is conceivable that some third-party standard-setters will establish very low, but transparent, standards" (Callison $2012,94)$. In addition, no third-party organization or governmental agency has the power to act against a benefit corporation that does not meet its objectives.

While existing legal forms in the U.S. seem, on the whole, ill-fitting and a significant challenge for many social enterprises, each form does offer some benefits for these organizations, and many of these entities have clearly figured out how to sustain themselves by adapting to whichever legal form they select. Even founders of social enterprises are unlikely to feel completely crippled by the constraints imposed by their organization's legal structure. Understandably, founders may feel frustrated by the real handicaps, as described above, that come along with any of the available choices in legal form. However, as Child, Witesman, and Braudt (2015) point out, founders choose a sector, or legal form for their organizations, not only for instrumental reasons that is, for what is best for the organization according to a rational, cost-benefit analysis - but also for expressive motivations (e. g., the founder seeks to be true to whoever he or she is), relational judgments (e. g., the founder responds to peers and others), and idiosyncratic historical constraints that also influence founders. Thus, for 
founders, frustration arising from the instrumental costs of picking any particular legal form is apt to be at least somewhat offset by the comfort of satisfying expressive or relational motivations. That is, founders do not only see existing legal forms as entirely ill-fitting and a challenge but also as offering an opportunity for fulfilling some personal needs and motivations.

\section{Covernance Challenges}

According to Ebrahim, Battilana, and Mair (2014, 82), organizational governance serves to "articulate both for what an organization is accountable, and to whom it is primarily accountable." The authors identify "two key challenges of governance they[, social enterprises,] face: accountability for dual performance objectives and accountability to multiple principal stakeholders" (p. 81). Specifically, "they combine not only potentially conflicting goals (social and financial) but also potentially divergent stakeholder interests" (p. 82).

In terms of the first challenge, accountability to two different goals, the authors see the risk of "mission drift" (p. 82). Noting that "a number of social enterprises have been criticized for ultimately prioritizing financial gains at the expense of their social mission," Ebrahim and his colleagues theorize that there exists a "temptation to assess performance in terms that are clear with well-established definitions and benchmarks (financial results) rather than in terms that are ambiguous with few established benchmarks and greater potential to be contested (social results)" (pp. 84, 88). That is, clear financial goals and measures may displace more vague and flexible social goals and measures.

Ebrahim and his colleagues argue that governance challenges differ based on whether the social enterprise is "integrated," where beneficiaries are embedded in the business, perhaps as employees or customers, or "differentiated," where business activities and mission-related activities are separate. They say that "this risk [of neglecting social results] is especially pronounced in integrated hybrids where good financial performance can mask poor social performance," whereas "in differentiated hybrids, the separation of commercial and social activities enables their performance to be monitored separately" (pp. 88-89). In other words, with subtle alterations to the beneficiary group in an integrated hybrid - for example, engaging middle-income rather than low-income stakeholders - the organization's mission could easily be lost.

The second challenge relates to stakeholder accountability. For-benefit organizations are distinguished by having multiple stakeholder groups whom they embed in organizational operations (Fourth Sector Group 2016). It is likely that this will be an area of challenge for social enterprises, as it has been an area in which the nonprofit sector is seen as having fallen short, too often prioritizing funders over beneficiaries (Jordan and Van Tuijl 2006). In theory, more nonprofits could use participatory approaches to governance (Mosley 2016). However, in practice, nonprofit boards are usually made up of "high-powered people" who are donors and/or fundraisers for the organization and do not often include other stakeholders (Taylor, Chait, and Holland 1996).

With regard to stakeholder accountability, Ebrahim and his colleagues again argue that there are differences between the integrated and differentiated social enterprises, with the latter especially prone to challenges. For differentiated hybrids, where customers differ from beneficiaries, customers may have an exit option - that is, they can purchase goods or services from other organizations - and so the social enterprise pays particular attention to doing what is necessary to hold on to them (the customers). Thus, there is significant risk that differentiated social enterprises will preference customers over beneficiaries, who may not have meaningful exit options, and that "managers [will] fail to invest the additional resources in improving or scaling ... social activities, choosing instead to further grow ... [the] business or capturing those excess revenues for themselves" (Ebrahim, Battilana, and Mair 2014, 89-90).

Ebrahim and his colleagues believe that these governance issues will be remedied not by new legal forms, which offer little guidance on such conflicts, but by "explicit organizational governance processes and mechanisms" (p. 84). In integrated hybrids, accountability mechanisms should focus on "overseeing the behavior of the vendors of the integrated product or service" since one risk is "that the commercial activities provide little social benefit to the poor or that they do not reach the poor" (pp. 90, 93). In differentiated hybrids, the greatest risk is that revenue is funneled to customers or executives rather than beneficiaries, and thus accountability mechanisms should focus on "monitoring ... the senior managers who head the separate commercial and social activities of the organization, as well as those who bring together both portfolios and thus determine the appropriate relationships and revenue transfer between them" (p. 90).

Differentiated hybrids should also create more stakeholder accountability by "providing beneficiaries with direct representation on the governing board, giving them a say in the organization's activities" and soliciting their feedback through surveys and other mechanisms (Ebrahim, Battilana, and Mair 2014, 93). Of course, as is the case with nonprofits generally, a danger is that board representation can turn out to be mostly tokenism with a beneficiary on the board having little impact on decision-making. Attendance can be an issue since 
beneficiary board members are more likely than other board members to work multiple jobs or have single parent caretaking responsibilities. Even when they are present, they may be less likely to speak up, perhaps because they are in an unfamiliar or intimidating setting. Having a critical mass of beneficiaries on a board may be helpful in ensuring the beneficiary voice is actually heard (Fredette and Bernstein 2019). In any case, board seats for beneficiaries may be more symbolic, representing a commitment to stakeholder involvement in governance, than consequential in terms of board decision making. As Ebrahim, Battilana, and Mair $(2014,93)$ put it, adding beneficiaries to boards is "not a straightforward task, requiring processes for legitimate selection, and training to build the capacities of beneficiaries to contribute to board deliberations."

\section{Difficulties in Measuring Impact}

Measuring impact is another major challenge facing social enterprises (Dees et al. 2008). There are several reasons for this. Social enterprises are often focused on making systemic social change, which is notoriously difficult to measure. In addition, social enterprises have to demonstrate both their profitability and social outcomes, which presents challenges because it involves collecting and analyzing very different kinds of data. There is also greater pressure on social enterprises to justify their impact, given that they are a relatively new type of organization and have to prove their commitment to profit and purpose.

The challenge of measuring social impact has plagued the nonprofit field for some time and is difficult for many social enterprises as well. As social enterprise expert Greg Dees and his colleagues $(2008,8)$ put it, "Impact assessment is still a crude and inexact science." In fact, there is still disagreement about exactly what "impact" means. Ebrahim and Rangan $(2014,120)$ suggest distinguishing between "outcomes" and "impacts," "with the former referring to lasting changes in the lives of individuals and the latter to lasting results achieved at a community or societal level."

To measure performance, nonprofit organizations may employ logic models that identify and link organizational inputs, activities, outputs, outcomes, and impacts. Funders have increasingly pushed organizations to measure outcomes and impact. However, causality and comparability remain problems in social impact assessment (Ebrahim, Battilana, and Mair 2014). Outcomes and impacts frequently depend on factors beyond the control of any single organization, and so are difficult for an organization to measure accurately (Ebrahim and Rangan 2014). Few organizations can afford the type of research designs, such as randomized controlled trials, that prove a causal link between a program and its outcomes. Moreover, the typical approach of evaluating programs based on an organization-specific logic model precludes comparability across organizations.

At the same time, increased attention to evaluation in the nonprofit sector has led to improvements in the impact assessment field. One recent study found that there are more than 70 different social impact assessment models that may be useful to social enterprises (Grieco, Michelini, and Iasevoli 2015). One-quarter of assessment models are specifically geared toward evaluating social impact with fewer, five percent, examining economic and environmental impact. More than three-quarters of the models are generic enough to be applied across organizations and industries. Such tools are quickly improving with new technologies and greater usage.

Moreover, there is also thoughtful pushback against pressing mission-oriented organizations, including social enterprises, to always seek to measure outcomes and impacts. For example, Ebrahim and Rangan (2014, 128) suggest that all organizations should measure inputs and outputs, which are often relatively straightforward to assess, but that only those organizations with sufficient control over outcomes should measure at this level. For example, the Indian organization Aravind performs hundreds of thousands of eye surgeries each year - its output. Because of the narrow scope of its mission, Aravind can relatively easily determine that its outcomes - improved eyesight for a similarly large number of individuals - have also been impressive (Ebrahim and Rangan 2014, 123-124).

Just as some social enterprises struggle appropriately or inappropriately to measure their social impact, some also grapple with the challenge of measuring both social and economic performance. Resources are scarce for implementing performance measurement in many social enterprises, and it can be a challenge to track both social and financial indicators, especially the former, particularly when different stakeholders pull in different directions.

Nevertheless, as with the other challenges we describe, some social enterprises have found ways to address the difficulty of measuring performance. Battilana and her colleagues (2019) report, "Our research has found that [dual-purpose] companies succeed by dedicating substantial time and effort to developing a manageable number of trackable metrics during the goal-setting process and revisiting them regularly to assess their continuing relevance and adequacy." 


\section{Lack of a Clear Identity}

The novelty of social enterprise in the U.S. poses several challenges to organizations, including a widespread lack of understanding by investors and consumers about what social enterprises are and do (Dees et al. 2008). Part of the reason for this unfamiliarity is that there is no common definition of social enterprise accepted by leaders in the field, with practitioners and scholars disagreeing about the definitions of and difference between "social enterprise" and "social entrepreneurship," for example. Commentators also debate about the extent to which social enterprise should focus on incremental versus systemic change and just how dominant earned income should be as a funding stream for social enterprises. Some push for a common definition of social enterprise (Dees et al. 2008) while others argue against a universal definition across countries because of differences in "culture, form of government, model of civil society, and stage of economic development" (Kerlin, Monroe-White, and Zook 2016, 68).

Whether there should be a consensus definition or not, a lack of common identity poses challenges to social enterprises. A lack of a shared understanding of social enterprise has hindered the development of a strong "community of practice" including collaboration, information sharing, and joint advocacy efforts (Dees et al. 2008 , 3). In addition, "what seems really at stake beyond conceptual debates are the place and the role of social enterprise within the overall economy and its interaction with the market, the civil society and public policies" (Defourny and Nyssens 2012, 72).

There are also political ramifications for how the field defines itself. With this lens, one study examined "public statements from the leading paradigm-building actors," largely government, foundations, fellowship organizations, and network organizations, to see which narratives about social enterprise might win out. Nicholls found conflicts between those "that propose business and commercial models as being central [", which is the social enterprise mentality driven by governments,"] ... and those that set social entrepreneurship within a framework of advocacy and social change" (2012, 230-237). The former says that "business-like social action is more 'responsive' to its social mission and beneficiaries" and the latter focuses on "giving beneficiaries a voice" (pp. 230-237). If the second narrative becomes dominant, Nicholls predicts that this will align social entrepreneurship and potentially social enterprise with "the cooperative, communitarian traditions of left-wing politics and ideology" (p. 235), which could decrease the likelihood that social enterprise is seen as a bipartisan issue in the U.S.

Social enterprises may also face opposition from organizations or sets of organizations that feel threatened by their existence. Battilana and Lee $(2014,411)$ observe that "at least one industry association representing the traditional charity sector has publicly announced their opposition to legislation that would provide legitimacy and benefits to social enterprises pursuing business and social goals."

Battilana and Lee (2014) also find that the conflicts between social and economic goals inherent in social enterprises can be resolved in ways that undermine the hybrid nature of these organizations. They point out that, "Overall, because of ... external and internal challenges, hybrids are prone to goal displacement and 'drift' toward better-established forms .... Such drift may enhance the future prospects of the organization through the circumvention of internal and external challenges associated with hybridity, but threaten to compromise its hybrid nature" (p. 412).

\section{Problems in Accessing Capital}

A lack of understanding and trust of social enterprise among customers and funders also poses a clear challenge in terms of access to capital (Battilana and Lee 2014,410). Many customers do not know what social enterprise is, and there is increasing skepticism among consumers about companies' claims of doing good. Among funders, there is "strong ambivalence regarding commercialization" of the nonprofit sector (McInerney 2012, 164-166). In fact, research has shown that "nonprofit organizations that generate earned revenues may also see donative revenues decline" because funders are skeptical of such activities (pp. 164-166).

And there is evidence that social enterprises operating in the nonprofit sector face other doubts as well. One study found that foundations have been slow to fund social enterprises (Dees et al. 2008). In addition, foundations are generally interested in funding new ventures, but are less interested in helping organizations scale up (Dees et al. 2008, 18). McInerney points to one solution, arguing that "Justification is the basis of legitimation" (p. 165), and that social enterprises must "defend successfully their organizational forms and practices within a given organizational field" (p. 166). This would require social enterprises to establish themselves as part of the nonprofit or for-profit sector before they can form their own sector. In other words, "legitimization processes at the intra- and inter-organizational levels can produce effects at the field level, which can, under the right circumstances, effect institutional change" (p. 166). 
On the for-profit side, investors are skeptical of the return-on-investment from social enterprise, despite evidence that social impact investment funds perform on-par with conventional funds (Dees et al. 2008). ${ }^{4}$ There is also a tendency for social financial markets to be "fragmented around different causes or interests" and "relatively small compared to mainstream capital markets" (Dees et al. 2008, 15). Because social financial markets are small and social enterprises differ so much, the search costs of matching investors with organizations are often high. In addition, the structure of current impact investments does not always fit the needs of social enterprises (Brakman Reiser and Dean 2017). Brakman Reiser and Dean argue that hybrid organizations need new financial products in addition to new legal forms. Battilana and Lee $(2014,411)$ point out that the nascent and growing field of social impact investing, which prioritizes support for hybrids, offers some promise of new assistance for social enterprises, although it currently accounts for a relatively modest amount of funding.

A 2017 survey by Halcyon Incubator and its partners of more than 400 social entrepreneurs confirmed some of these financial challenges (Halcyon 2017). While the ventures in the sample were likely smaller than the typical social enterprise, the results showed that nearly two-thirds (65 percent) relied on self-financing, 41 percent received grants, and seven percent received venture capital (respondents could select multiple categories). ${ }^{5}$ Social entrepreneurs reported difficulty finding like-minded investors. Another overarching challenge for social enterprises trying to earn income is that the resource pool of the targeted customer population may simply fall short. For example, a social enterprise marketing its products strictly to low-income populations may not be able to raise the capital it needs to sustain and/or grow its operations through sales.

Government and philanthropy can be important funders of the social service side of social enterprises and can help buffer these entities against business pressures (Cooney 2011, 91). However, government in the U.S. can be a fickle funder of social enterprises. Compared to their European counterparts, work integrated social enterprises (WISEs) in the U.S. have fewer policy supports, such as government subsidies and procurement setasides (Cooney et al. 2016, 424-425; Cooney 2016, 436). As an example of what can happen with government contracts, one well-known WISE in the Washington, DC area, DC Central Kitchen, recently lost its longstanding contract to provide food service to the city's homeless shelters. DC Central Kitchen works with the homeless, former prisoners, recovering drug and alcohol addicts, and others with employment-related challenges, training them to become chefs and employees at the Kitchen. DC Central Kitchen lost its contract to provide meals at Washington's largest shelters to Henry's Soul Cafe, a small, for-profit restaurant and catering business that is a "Certified Business Enterprise" in the District of Columbia which entitles it to preference in procurement (Moyer 2019a, 2019b). Somewhat ironically, the for-profit Henry's receives a leg up in the government procurement process while the nonprofit DC Central Kitchen does not, although DC Central Kitchen does enjoy some other advantages by being a nonprofit.

\section{Management Tensions}

The existing, empirical literature on social enterprises documents how these entities cope - often with some hardship - with the management tensions that come along with being a social enterprise. While all organizations likely experience some degree of management tension, organizations where there is extreme conflict or important differences that remain unresolved for long periods are likely to suffer some dysfunction. In social enterprises, conflict can arise over allocating resources between social service and commercially-oriented activities; maintaining a steady flow of client-workers to the business side of the organization; balancing business pressures for clients to produce against time for client training; and coordinating ancillary client services, such as job clubs and English as a second language and General Equivalency Diploma (GED) classes (Battilana and Lee 2014, 411; Cooney 2006, 152-156).

Different kinds of social enterprises adapt in different ways to the pressures to accomplish both social and economic goals (Santos, Pache, and Birkholz 2015). As described in the section above on governance challenges, one broad strategy is to integrate social and economic activities, while another is to compartmentalize these functions and manage them separately (Battilana and Lee 2014). With either strategy, successful social enterprises can find ways to mitigate tensions between social and financial goals. Battilana and her colleagues (2019) suggest that dual-minded leadership can make strategic decisions that embody both goals; boards can also serve as guardians of both social and economic objectives; and employees can be hired and socialized to embrace both social and economic perspectives through communication, training, promotion and incentive systems, and job shadowing (see also Battilana and Dorado 2010; Battilana et al. 2015, 1678). ${ }^{6}$

One effective approach to addressing conflict, especially in social enterprises that have adopted a compartmentalized structure, is to use "spaces of negotiation" that facilitate coordination across separated groups. As Battilana and her colleagues $(2015,1676-1678)$ describe, spaces of negotiation can involve regular and mandatory meetings of representatives of both the social service and commercial divisions of a social enterprise; coor- 
dinated work plan scheduling; and performance appraisals for clients/beneficiaries that engage both production supervisors and social counselors.

While some social enterprises are successful in accommodating to and sustaining their split personalities, others resolve management tensions by drifting away from one or other of their defining purposes. As noted previously, some observers fear that, over time, social enterprises are apt to prioritize financial over social performance. For example, Cooney (2006) worries that the social service side of a social enterprise will lose out because of its flexibility in the face of a less flexible business side. Garrow and Hasenfeld (2014) are also concerned about social enterprises experiencing mission drift toward business goals and away from their social mission. In this context, Garrow and Hasenfeld $(2012,2014)$ are especially troubled about how clients are treated in social enterprises where market logic triumphs over social concerns. They find that clients experience commodification as production workers in these instances, and that their therapeutic, service needs are given short shrift.

\section{Conclusion}

This paper aims to increase understanding of the challenges facing social enterprises in order to inform public policy and other efforts to strengthen and grow the social enterprise field. Drawing on a review of the existing literature on social enterprises, this paper identifies a variety of challenges now facing social enterprises in the U.S. as well as some options for addressing these challenges:

\subsection{Legal Form}

The current literature suggests social enterprises do not fit very well into traditional nonprofit and for-profit legal forms, but also finds that some of the newer forms for hybrids that have been established within the forprofit sector, such as benefit corporations and L3Cs, have not yet had significant take up and do not seem like completely satisfactory solutions either. The new forms do not clearly prioritize social goals, and there has been little government monitoring and enforcement of legal requirements (Brakman Reiser 2013). Other hybrid legal structures, like cooperatives and employee-owned enterprises, are available in the U.S. but seem underutilized (Hansmann 1996; Democracy Collaborative 2005). These other options should be explored further, and the U.S. can also learn from legal structures used for social enterprises in other countries (Brewer 2016).

\subsection{Governance}

Existing research emphasizes the challenge for social enterprises of advancing the goals of both purpose and profit and satisfying multiple stakeholders with diverse interests. Efforts to include clients on organizational boards of directors can be problematic depending in part on the types of clients involved. Better training for all board members might help. Ebrahim, Battilana, and Mair (2014) suggest that social enterprises should also put into place explicit organizational procedures to prioritize dual goals.

\subsection{Measuring Impact}

Current research suggests that social enterprises will be especially challenged in evaluating social impact with the result that they may focus more heavily on financial rather than social impact measures. Work by Ebrahim and Rangan (2014) and others suggests that it may well be appropriate for social enterprises - like nonprofits generally - to measure inputs and outputs and only measure outcomes and impacts when that is justified by an organization's broad sphere of control. While performance measurement systems that can compare across many different kinds of social enterprises may be elusive, systems that focus on one specific field (e. g., microfinance, WISEs) are likely more feasible at least in the short-term.

\subsection{Identity}

The existing literature worries about the lack of peer networks for social enterprises. Social enterprises should take more initiative themselves in developing peer associations, and their philanthropic and government fun- 
ders could assist in these efforts. Social enterprises should also be considering ways to engage other kinds of organizations in supportive coalitions to increase the political clout of social enterprises.

\subsection{Funding}

According to current studies, nonprofit and for-profit social enterprises face significant, different challenges in finding needed funding. More innovative funding mechanisms, like impact investing, are being tried although they still only account for a modest level of resources. Government could be a steadier and larger funder of social enterprises by providing grants specifically to these entities and/or giving preferences in its procurement decisions.

\subsection{Management}

Management tensions are significant in many social enterprises, although these entities may find ways to reduce the conflicts somewhat. Prioritizing business over social goals is a particular danger for social enterprises. Battilana et al. (2019) offer a variety of strategies for social enterprises - or dual-purpose organizations as they call them - to address management challenges, including through dual-minded leadership, hiring and socializing employees to embrace both social and commercial goals, structuring organizations to pursue both objectives, and others.

Existing research provides important signals about current challenges now facing social enterprises and provides some guidance to social enterprise leaders and those in government, foundations, nonprofits, and business interested in strengthening the support system for social enterprise. However, at the same time, additional research is needed to provide more refined direction to the increasing number of initiatives seeking to fortify public policy and the broader ecosystem for social enterprise. Additional research should test - through interviews, focus groups, and/or surveys - the accuracy of the analysis in this paper which identified six major challenges focusing on social enterprises. Finally, much more work needs to be done in identifying and testing creative ways to address the challenges discussed in these pages.

\section{Notes}

1 The authors recognize that definitional issues related to "hybrid" organizations and "social enterprise" are not entirely settled. In this paper, we follow some of the leading scholars in the field who hold that social enterprises rely mainly on earned income and have a primary social or environmental mission (Young, Searing, and Brewer 2016; Alter 2007; Child 2010). Here we also follow Young, Searing, and Brewer (2016) in using the term social enterprise broadly to refer to organizations in any sector that fit these criteria.

2 See, for example, efforts to bolster impact investing that supports social enterprises. The Global Impact Investing Network (GIIN) seeks to attract increased private investment capital to address pressing global challenges by supporting double-bottomline organizations (https://thegiin.org/). In the Obama administration, the White House Office of Social Innovation and Civic Participation and the Social Innovation Fund in the Corporation for National and Community Service helped advance social enterprise (Truhe and Schorr 2016). The Fourth Sector Group seeks to advance a broad strengthening of the ecosystem supporting what it calls "for-benefit" organizations (https://www.fourthsector.org/). "A Deeper Dive: Social Enterprise Ecosystems in the U.S." provides information on the support systems for social enterprise in 21 cities across the U.S., see: https://socentcity.org/sites/default/files/report/Social\%20Enterprise\%20Ecosystems\%20-\%20Year\%202.pdf.

3 For other papers that have relatively comprehensive accounts of the broad range of challenges facing social enterprises, see, for example, Battilana et al. (2012), and Dees et al. (2008).

4 A 2015 study by Cambridge Associates and the Global Impact Investing Network found a 15 percent lower rate of return, 6.9 percent versus 8.1 percent, for impact investors versus conventional investors, "but for funds less than $\$ 100$ million, impact funds more than doubled the return of conventional funds: 9.5 percent versus 4.5 percent." (Tyler III 2016, 262). A similar study by Morgan Stanley in 2015 found that "returns from investments in sustainable companies either met or exceeded absolute and risk-adjusted returns." It also found a positive correlation between sustainable activity and stock price, and one social investment mutual fund that started in 1990 outperformed the S\&P 500 by 45 basis points (p. 263).

5 As a comparison, according to data from the U.S. Census Bureau's 2016 Annual Survey of Entrepreneurs, when asked about the sources of capital used to start up or acquire a business, 64.4 percent of firms with paid employees reported using the personal/family savings of owners, 16.5 percent reported getting a business loan from a bank or financial institution, 9.1 percent reported using a personal credit card, 0.5 percent reported receiving a business loan from government, and 0.5 percent reported receiving an investment by venture capitalists (not all sources of funds reported here) (U.S. Bureau of the Census 2018).

6 Battilana and Dorado (2010) describe some of the different ways that social enterprises - in their study two new Bolivian microfinance organizations - can hire and socialize employees to serve both social and economic goals. For example, organizations can use a "tabula rasa" approach, hiring inexperienced staff right from university with the idea of training and socializing them with the skills and values needed by the organizations. Using a contrasting "mix and match" approach, organizations hire staff who already have the different capabilities the organizations need (e. g., lending and development experience). As Battilana and Dorado point out, different management strategies come with different advantages and disadvantages. 


\section{References}

Abramson, A.J., and K.C. Billings. Forthcoming 2019. "New Legal Forms for Hybrid Organizations," In Routledge Companion for Nonprofit Management, edited by H. Anheier, and S. Toepler. London: Routledge.

Alter, K. 2007. "Social Enterprise Typology." Accessed October 22, 2018. https://s3.amazonaws.com/academia.edu.documents/32431718/ SE_typology.pdf?AWSAccessKeyId=AKIAIWOWYYCZ2Y53UL3A\&Expires=1540237954\&Signature=LaA\%2Bx8dSbmOYgx9Lh22K\%2 BWP\%2BFrA\%3D\&response-content-disposition=inline\%3B\%20filename\%3DSocial_Enterprise_Typology_Updated_Novem.pdf

B Lab. 2017a. “FAQ: Ceneral Questions". Accessed December 16, 2017. http://benefitcorp.net/faq.

B Lab. 2017b. "Model Benefit Corporation Legislation". Accessed September 10, 2018. http://benefitcorp.net/attorneys/model-legislation.

Bainbridge, S. M. 1991. “Interpreting Nonshareholder Constituency Statutes.” Pepperdine Law Review 19: 971-1025.

Battilana, J., and S. Dorado. 2010. “Building Sustainable Hybrid Organizations: The Case of Commercial Microfinance Organizations." Academy of Management Journal 53 (6): 1419-40.

Battilana, J., and M. Lee. 2014. "Advancing Research on Hybrid Organizing - Insights from the Study of Social Enterprises." The Academy of Management Annals 8 (1): 397-441.

Battilana, J., M. Lee, J. Walker, and C. Dorsey. 2012. "In Search of the Hybrid Ideal." Stanford Social Innovation Review (Summer): 50-55. Accessed October 1, 2017. https://ssir.org/articles/entry/in_search_of_the_hybrid_ideal.

Battilana, J., A. Pache, M. Sengul, and M. Kimsey. 2019. "The Dual-Purpose Playbook: What It Takes to Do Well and Do Good at the Same Time." Harvard Business Review 97 (2): 124-33.

Battilana, J., M. Sengul, A. Pache, and J. Model. 2015. “Harnessing Productive Tensions in Hybrid Organizations: The Case of Work Integration Social Enterprises." Academy of Management Journal 58 (6): 1658-85.

Bradley, B., P. Jansen, and L. Silverman. 2003. “The Nonprofit Sector's \$100 Billion Opportunity.” Harvard Business Review 81 (5): 94-103.

Brakman Reiser, D. 2011. “Benefit Corporations: A Sustainable Form of Organization.” Wake Forest Law Review 46: 591-624.

Brakman Reiser, D. 2013. "Theorizing Forms for Social Enterprise." Emory Law Journal 62: 681-96.

Brakman Reiser, D., and S. A. Dean. 2017. Social Enterprise Law: Trust, Public Benefit and Capital Markets. Oxford, U.K.: Oxford University Press.

Brewer, C. V. 2016. "The Ongoing Evolution in Social Enterprises Legal Forms." In The Social Enterprise Zoo: A Guide for Perplexed Scholars, Entrepreneurs, Philanthropists, Leaders, Investors, and Policymakers, edited by D. R. Young, E. A. Searing, and C. V. Brewer, 33-64. Cheltenham, UK and Northhampton, MA, USA: Edward Elgar Publishing.

Callison, J. W. 2012. "Putting New Sheets on a Procrustean Bed: How Benefit Corporations Address Fiduciary Duties, the Dangers Created, and Suggestions for Change." American University Business Law Review 2: 85-114.

Child, C. 2010. "Whither the Turn? the Ambiguous Nature of Nonprofits' Commercial Revenue." Social Forces 89 (1): 145-61.

Child, C., E. M. Witesman, and D. B. Braudt. 2015. "Sector Choice: How Fair Trade Entrepreneurs Choose between Nonprofit and For-Profit Forms." Nonprofit and Voluntary Sector Quarterly 44 (4): 832-51.

Community Wealth Ventures, Social Enterprise Alliance, and Center for Advancement of Social Enterprise. Social Enterprise: A Portrait of the Field 2010. Accessed March 15, 2018. https://community-wealth.org/sites/clone.community-wealth.org/files/downloads/report-cwv-seacase.pdf.

Cooney, K. 2006. "The Institutional and Technical Structuring of Nonprofit Ventures: Case Study of a U.S. Hybrid Organization Caught between Two Fields." Voluntas 17: 143-61.

Cooney, K. 2011. "The Business of Job Creation: An Examination of the Social Enterprise Approach to Workforce Development." Journal of Poverty 15 (1): 88-107.

Cooney, K. 2016. “Work Integration Social Enterprises in the United States: Operating at the Nexus of Public Policy, Markets, and Community." Nonprofit Policy Forum 7 (4): 435-60.

Cooney, K., J. Koushyar, M. Lee, and H. Murray. 2014. “Benefit Corporation and L3C Adoption: A Survey." Stanford Social Innovation Review (December 5). Accessed October 1, 2017. https://ssir.org/articles/entry/benefit_corporation_and_l3c_adoption_a_survey.

Cooney, K., M. Nyssens, M. M. O’Shaughnessy, and J. Defourny. 2016. “Public Policies and Work Integration Social Enterprises: The Challenge of Institutionalization in a Neoliberal Era." Nonprofit Policy Forum 7 (4): 415-33.

Dees, J. G., M. Nash, B. Anderson, J. Kalafatas, R. Tolman, W. Kuran, and P. Bloom. 2008. “Developing the Field of Social Entrepreneurship." Center for the Advancement of Social Entrepreneurship, Duke University. Accessed October 22, 2018. https://communitywealth.org/sites/clone.community-wealth.org/files/downloads/paper-case.pdf.

Defourny, J., and M. Nyssens. 2012. "Conceptions of Social Enterprise in Europe: A Comparative Perspective with the United States." In Social Enterprises: An Organizational Perspective, edited by B. Gidron, and Y. Hasenfeld, 71-90. Houndmills, Basingstoke, Hampshire, U.K.: Palgrave Macmillan.

Democracy Collaborative. 2005. Building Wealth: The New Asset-Based Approach to Solving Social and Economic Problems. Washington, DC: Aspen Institute.

Ebrahim, A., J. Battilana, and J. Mair. 2014. “The Covernance of Social Enterprises: Mission Drift and Accountability Challenges in Hybrid Organizations." Research in Organizational Behavior 34: 81-100.

Ebrahim, A., and V. K. Rangan. 2014. "What Impact?: A Framework for Measuring the Scale and Scope of Social Performance." California Management Review 56 (3): 118-41.

Esposito, R. T. 2012. “The Social Enterprise Revolution in Corporate Law: A Primer on Emerging Corporate Entities in Europe and the United States and the Case for the Benefit Corporation." William and Mary Business Law Review 4: 639-714.

Foster, W., and G. Fine. 2007. "How Nonprofits Get Really Big." Stanford Social Innovation Review 5 (2): 46-55.

Fourth Sector Group. 2016. "Fourth Sector Taxonomy Framework." Working Draft. Fourth Sector Mapping Initiative. November 12, 2016.

Fredette, C., and R. S. Bernstein. 2019. "Ethno-Racial Diversity on Nonprofit Boards: A Critical Mass Perspective." Nonprofit and Voluntary Sector Quarterly. https://journals.sagepub.com/doi/10.1177/0899764019839778. 
Garrow, E., and Y. Hasenfeld. 2012. "Managing Conflicting Institutional Logics: Social Service versus Market." In Social Enterprises: An Organizational Perspective, edited by B. Gidron, and Y. Hasenfeld, 121-43. Houndmills, Basingstoke, Hampshire, UK: Palgrave Macmillan.

Garrow, E., and Y. Hasenfeld. 2014. "Social Enterprises as an Embodiment of a Neoliberal Welfare Logic." American Behavioral Scientist 58 (11): 1475-93.

Cibbons, J., and J. Hazy. 2015. "Growing a Large-Scale Social Enterprise: How Goodwill Industries (R) Succeeds as a Hybrid Organization." Paper presented at the Annual Meeting of the Academy of Management, Vancouver, BC.

Cottesman, M. D. 2007. "From Cobblestones to Pavement: The Legal Road Forward for the Creation of Hybrid Social Organizations." Yale Law \& Policy Review 26 (1): 345-58.

Grieco, C., L. Michelini, and G. lasevoli. 2015. “Measuring Value Creation in Social Enterprises: A Cluster Analysis of Social Impact Assessment Models." Nonprofit and Voluntary Sector Quarterly 44 (6): 1173-93.

Halcyon. 2017. “A Deeper Dive: Social Enterprise Ecosystems in the U.S." Accessed January 29, 2018. http://socentcity.org.

Hansmann, H. 1996. The Ownership of Enterprise. Cambridge, MA: Belknap Press.

Jordan, L., and P. Van Tuijl eds. 2006. NCO Accountability: Politics, Principles and Innovations. London, UK: Earthscan.

Kerlin, J. A., and K. Gagnaire. 2009. "United States." In Social Enterprise: A Global Comparison, edited by ]. Kerlin, 87-113. Medford, MA: Tufts University Press/ Hanover, $\mathrm{NH}$ : University Press of New England.

Kerlin, J. A, T. Monroe-White, and S. Zook. 2016. "Habitats in the Zoo." In The Social Enterprise Zoo: A Guide for Perplexed Scholars, Entrepreneurs, Philanthropists, Leaders, Investors, and Policymakers, edited by D. R. Young, E. A. Searing, and C. V. Brewer, 67-92. Cheltenham, UK and Northhampton, MA, USA: Edward Elgar Publishing.

Kickul, J., and T. S. Lyons. 2012. Understanding Social Entrepreneurship: The Relentless Pursuit of Mission in an Ever Changing World. New York: Routledge.

McInerney, P. B. 2012. “Social Enterprise in Mixed-Form Fields: Challenges and Prospects." In Social Enterprises: An Organizational Perspective, edited by B. Gidron, and Y. Hasenfeld, 162-84. Houndmills, Basingstoke, Hampshire, UK: Palgrave Macmillan.

Mickels, A. 2009. "Beyond Corporate Social Responsibility: Reconciling the Ideals of a For-Benefit Corporation with Director Fiduciary Duties in the U.S. And Europe." Hastings International and Comparative Law Review 32 (1): 271-304.

Mosley, J. E. 2016. "Nonprofit Organizations' Involvement in Participatory Processes: The Need for Democratic Accountability." Nonprofit Policy Forum 7 (1): 77-83

Moyer, J. W. 2019a. “D.C. Central Kitchen Loses Part of Contract to Feed Homeless.” Washington Post, March 18, 2019.

Moyer, J. W. 2019b. “D.C. Council Member Asks for Probe of Contract with Caterer to Feed the Homeless." Washington Post, April 2, 2019.

Nicholls, A. 2012. "Postscript: The Legitimacy of Social Entrepreneurship: Reflexive Isomorphism in a Pre-Paradigmatic Field." In Social Enterprises: An Organizational Perspective, edited by B. Gidron, and Y. Hasenfeld, 222-49. Houndmills, Basingstoke, Hampshire, UK: Palgrave Macmillan.

Santos, F., A. Pache, and C. Birkholz. 2015. “Making Hybrids Work: Aligning Business Models and Organizational Design for Social Enterprises." California Management Review 57 (3): 36-58.

SocEntCity.org. "A Deeper Dive: Social Enterprise Ecosystems in the U.S.” vol. 2. https://socentcity.org/sites/default/files/report/ Social\%20Enterprise\%20Ecosystems\%20-\%20Year\%202.pdf.

Social Enterprise Law Tracker. 2017. "Status Tool." New York University School of Law and New York University Stern School of Business. Accessed December 14, 2017. http://socentlawtracker.org/\#/spcs.

Social Impact Investment Taskforce. 2014. “Impact Investment: The Invisible Heart of Markets." Accessed December 17, 2017. http://www.ietp.com/sites/default/files/Impact\%2olnvestment\%20Report\%20FINAL.pdf.

Stout, L. A. 2012. The Shareholder Value Myth: How Putting Shareholders First Harms Investors, Corporations, and the Public. San Francisco: BerrettKoehler Publishers

Taylor, B., R. P. Chait, and P. Holland. 1996. “The New Work of the Nonprofit Board.” Harvard Business Review 74 (5): $36-46$.

Thomson Reuters Foundation. 2016. "Which Legal Structure Is Right for My Social Enterprise? A Cuide to Establishing Social Enterprise in the U.S." Thomson Reuters Foundation. Accessed October 22, 2018. https://www.trust.org/contentAsset/raw-data/1b34bbc3-de52-477aadae-850a56c2aabe/file.

Truhe, N., and J. Schorr. 2016. “One Thing U.S. Presidential Candidates Can Agree On: Social Enterprise Works." Stanford Social Innovation Review (August 2). Accessed September 9, 2018. https://ssir.org/articles/entry/one_thing_us_presidential_candidates_can_agree_on_social_enterprise_works.

Tyler, J. E., III. 2016. "Social Impact of the Social Enterprise Zoo." In The Social Enterprise Zoo: A Guide for Perplexed Scholars, Entrepreneurs, Philanthropists, Leaders, Investors, and Policymakers, edited by D. R. Young, E. A. Searing, and C. V. Brewer, 258-84. Cheltenham, UK and Northhampton, MA, USA: Edward Elgar Publishing.

U.S. Bureau of the Census. 2018. "Statistics for U.S. Employer Firms by Sources of Capital Used to Start or Acquire the Business by Sector, Gender, Ethnicity, Race, Veteran Status, and Years in Business for the U.S., States, and Top 50 MSAs: 2016." In American FactFinder: 2016 Annual Survey of Entrepreneurs. Table SE1600CSCBO7.

World Bank. 2013. "Crowdfunding's Potential for the Developing World." Accessed March 12, 2018. http://www.infodev.org/sites/default/files/infodev_crowdfunding_study_o.pdf.

Young, D. R., E. A. Searing, and C. V. Brewer. 2016. The Social Enterprise Zoo: A Guide for Perplexed Scholars, Entrepreneurs, Philanthropists, Leaders, Investors, and Policymakers. Cheltenham, UK and Northhampton, MA, USA: Edward Elgar Publishing. 